- department of genetics at Washington University in St Louis, told the committee that because Celera has access to that scaffold - as well as to the public project's data - it will always be ahead in the gene mapping effort.

Waterston believes that Celera's level of coverage, when assembled, will result in over 40,000 gaps. He based his estimate on Celera's sequence of the fruitfly Drosophila, which, at a fraction of the size of the human genome, contained about 1,200 gaps. Green says the number of gaps in Celera's human sequence might be higher, as the company did not sequence the genome as many times over as it did the Drosophilagenome.

Nevertheless, Waterston, Celera's president Craig Venter and Neil Lane, President

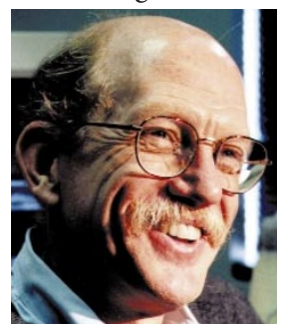

Bill Clinton's science adviser, all said at the subcommittee hearing that a formal collaboration would result in a better quality genome than either group could produce on its own. Indeed, each side may 40,000 sequence gaps. have something the other desires.

Although Celera has access to the public data, it has no guarantee that publicly funded scientists will volunteer to help annotate the human genome and fill in any gaps that remain once the two data sets are merged.

Public scientists participated in an 'annotation jamboree' for sequencing the genome of Drosophila. But that was on the understanding that the fruits of their labour would be available in GenBank, the publicly funded database. Celera has said it will make its version of the human genome available publicly, but only in its own database, and with restrictions on the use and redistribution of sequence data (see Nature 404, 324; 2000).

The public project, in turn, could use Celera's data to move up the completion date of its own project. The HGP has planned for a 'rough draft' of the genome with $5 \mathrm{X}$ sequence coverage by the end of this year, and a complete copy with 10X coverage in 2003.

Celera also plans to release its draft of the human genome by the end of this year - but only after it is fully assembled. By contrast, scientists can see new data being added to GenBank by the public project every 24 hours. This discrepancy between the two approaches has blocked formal cooperation from the beginning.

Celera's insistence that scientists should not be able to download, add to or redistribute information from either its prospective free or current public databases has placed further obstacles in the way of collaboration. Resolving them would allow for a more comprehensive human genome database sooner than either the public or private projects initially anticipated.

Paul Smaglik

\title{
German parliament agrees on limits to bioethics inquiry
}

\section{Munich}

The German parliament last week ended 18 months of controversy by deciding to set up an all-parliamentary commission d'enquête (commission of inquiry) on the ethical and legal aspects of biomedicine.

Opponents of such a commission had included Wolf-Michael Catenhusen, the biotechnology-friendly Social Democrat (SPD) secretary of research. He had feared that it would lead to cumbersome discussions of first principles that might delay legislation to bring the regulation of German biomedicine into line with the rest of Europe (see Nature 402, 331-332; 1999).

But the Greens - together with much of the media and the German public — had accused opponents of the commission of attempting to curtail political discussion about the ethical and social implications of biomedical and biotechnological progress.

Last week's compromise follows a reduction and streamlining of the inquiry panel's tasks. For example, the question of whether Germany should ratify the Council of Europe's Convention on Human Rights, which sets minimum ethical standards for European countries - but which Germany opposed because some clauses conflict with Germany's more restrictive national rules has been removed from the agenda.

Catenhusen welcomes the compromise. "I am optimistic that the commission will focus on really important issues, such as therapeutic cloning, now that we have turned away from setting up a combat group committed to fighting the Council of Europe Convention," he says.

The commission's purpose is now described as being to "work out recommendations for ethical assessment ... and for legislative and administrative action related to future medical opportunities". It will identify areas in which recent scientific developments have exposed a lack of appropriate legal rules, for example in stem-cell research or genetic testing.

Monika Knoche, the Green party's expert on medical ethics, says that genetic screening and reproductive technologies head the party's agenda for the commission.

The panel is scheduled to begin work next month, when its members - including 13 members of parliament and an equal number of external experts - will be nominated. It is not expected to include those holding 'extreme' positions. According to Catenhusen, this will reduce the chances of conflict found in the initial proposal, which would have included members known for their unwillingness to compromise.

Commissions d'enquête provide policy advice and prepare the introduction or modification of legislation. They are thus required to deliver final reports well before the end of a legislative period - a demand that, in the past, not all of them have been able to meet. Quirin Schiermeier \& Ulrike Hellerer

\section{Ontario joins the genomics goldrush}

\section{Montreal}

Canada's richest province, Ontario, is seeking to become an international force in genomics research. The Ontario Research and Development Challenge Fund (ORDCF) last week announced the approval of Can $\$ 74.2$ million (US\$51 million) for genomics-related projects. This sum will draw an additional Can\$134.7 million from research institutes and the private sector.

Ontario's plan predates the federal scheme to establish 'Genome Canada', comprising five national genome centres (see Nature 404, 8; 2000).

Last week's announcement of Ontario's projects was made by Jim Wilson, the province's energy, science and technology minister. Martin Godbout, named president of the national centre last month, has met with fund officials to discuss possible collaboration with Ontario's programme.
The projects approved for Ontario include a Centre for Genomic Computation, providing access to DNA sequences and analysis via the Internet. This will be housed at Toronto's Hospital for Sick Children, where new supercomputers have assumed management of the Genome Database of the international Human Genome Project. The database was transferred last year from Johns Hopkins University, Baltimore.

The Ontario Cancer Institute will host a proteomics facility, for producing pure proteins as drug targets, and a DNA microarray facility, for analysing information on the genetics of disease.

Each facility will serve the province as a whole. Seven more genomics proposals have been conditionally approved. Responses from the institutions involved, indicating whether all conditions have been met, are expected by the end of July. David Spurgeon 